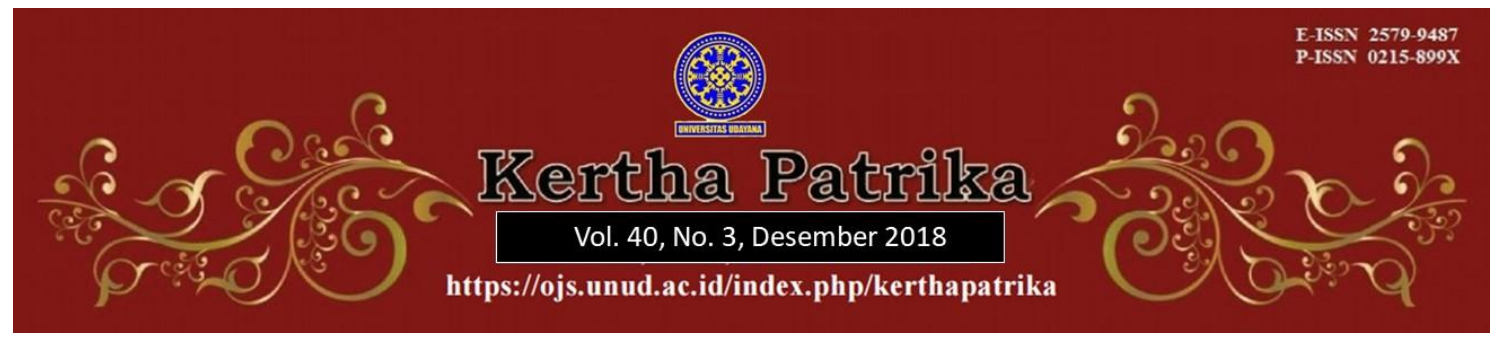

\title{
KHASHOGGI CASE AND THE ISSUE OF HUMAN RIGHTS PROTECTION OF JOURNALISTS
}

\author{
Migel Apriliyanto, ${ }^{1}$ Made Maharta Yasa ${ }^{2}$
}

${ }^{1}$ Faculty of Law Udayana University, E-mail: migel13.aprilianto.ma@gmail.com

2 Faculty of Law Udayana University, E-mail: mdmahartayasa@gmail.com

\begin{tabular}{l}
\hline Info Artikel \\
\hline Received : $1^{\text {st }}$ December 2018 \\
Accepted :30 $0^{\text {th }}$ December 2018 \\
Published :31 \\
Keyworts Der 2018 \\
Protection, International \\
Human Rights Law. \\
Corresponding Author: \\
Migel Apriliyanto, E-mail: \\
migel13.aprilianto.ma@gmai \\
1.com \\
DOI : \\
10.24843/KP.2018.v40.i03.p \\
01
\end{tabular}

Abstract
Jamal Khashoggi is known for his very sharp critics to Saudi
Arabian Governments. He was murdered at the Consulate
facility of Saudi Arabia in Istanbul- Turkey. The case has become
a concern of international society, put the questions of freedom of
expression and press as well the security of journalist. This
article is a normative legal research that is aimed to analyze the
international human rights law's protection to the journalist's
activities and to discuss the case of Khashoggi, specifically on the
issue which authorities that have obligations to impose legal
sanctions to the alleged perpetrators. The research suggests that
there have been international human rights norms and principles
that protect journalist activities. In addition, it suggests that
Turkey has jurisdiction to launch an investigation and prosecute
the perpetrators who involve in the murder of Jamal Khashoggi.

\section{Introduction}

The murder of Jamal Khashoggi case was one of the most shocking cases in the journalistic world. He worked at Washington Post as a journalist because of his sharpness when he criticizes Saudi Government. He argued that Saudi Arabia was supposed to be a democratic country if it wanted a better life for their citizen. The murder that happened to Khashoggi occurred on 2nd October 2018 located at Consular office of Saudi Arabia in Turkey. ${ }^{1}$ The Turkish authorities suspected that the murder of Khashoggi was the Saudi Government, yet the fact might not be like that. Saudi authorities admitted that the perpetrators come from its country, however, they stated that the killing was not organized by the Government of Saudi Arabia and was out of their reach. ${ }^{2}$

\footnotetext{
${ }^{1}$ CNN News, Kronologi Kisruh Jamal Khashoggi, Wartawan Pengkritik Saudi, Sabtu, https://www.cnnindonesia.com/internasional/20181019100032-120-339720/kronologikisruh-jamal-khashoggi-wartawan-pengkritik-saudi 20/10/2018

2 CNN News (2018). Klaim Saudi dan Upaya Jauhkan Pangeran dari Kasus Khashoggi, https:// www.cnnindonesia.com/internasional/20181020220049-120-340106/klaim-saudidan-upaya-jauhkan-pangeran-dari-kasus-khashoggi Sabtu, 20/10/2018
} 
Saudi Arabia is allegedly involved in this case because Jamal Khashoggi often criticized many of Saudi Arabia's policies in his articles; which makes everyone suspicious about what is the reason behind this murder. This complement the image of Saudi Arabia as a country that does not fully support the freedom of the press. ${ }^{3}$

Since there is no evidence can prove the reason behind this case yet, the Turkish Government urged Saudi authorities to deal with the suspect as soon as possible to be prosecuted before the Turkish Court for revealing the truth behind this matter. Turkey authorities said that Jamal Khashoggi was killed in just by a few minutes. It was revealed by the source who had listened to the entire recording before he gets executed. The recording was obtained from Khashoggi's Apple Watch, but there are many parties inquire about this recording. ${ }^{4}$ Saudi said that Khashoggi died because of bare hand fighting with one of the killers, but then after this recording has been found, it is clear that Khashoggi is not died because of the suspected reason. ${ }^{5}$ He was dragged from the main office to the working bench. Even the witness said they could hear his scream until they injected some kind of unknown liquid into his body. Some sources said that before Khashoggi died, he was beaten, tortured, and mutilated. ${ }^{6}$

Journalist protections have become a global concern because there is a significant increase regarding violence on journalists. Recognizing the importance of journalist safety and journalist freedom of expression, The General Assembly of the United Nations on January 29th, 2018 adopted Resolution No. A/RES/72/175 about the Safety of Journalists and the Issue of Impunity. This resolution is the legal basis for all journalists to get protection when they perform their duties. This resolution is imposed by referring the Universal Declaration of Human Rights (UDHR), International Convention on Civil and Political Rights (ICCPR), and the International Convention for the Protection of All Persons from Enforced Disappearance (ICPPED). ${ }^{7}$

This article is aimed to analyze the international human rights law's protection to the journalist's activities. Besides, it also discusses the case of Khashoggi, specifically on the issue which authorities that have obligations to impose legal sanctions to the alleged perpetrators.

\footnotetext{
${ }^{3}$ For example, the case of banned againts Qatari Al-Jazeera television network. See Fernandez, J. M. (2018). Special Report: The Qatar-Gulf Crisis: The Attack on Media Freedom and The West's Loss of Moral Authority. Pacific Journalism Review: Te Koakoa, 24(2), p.159, https://doi.org/10.24135/pjr.v24i1.401

${ }^{4}$ CNN News (2018). Turki Sebut Khashoggi Dibunuh Dalam Hitungan Menit, https://www.cnnindonesia.com/internasional/20181017174328-113-339273/turki-sebutkhashoggi-dibunuh-dalam-hitungan-menit,

${ }^{5}$ Ibid

${ }^{6}$ CNN News (2018). Momen Penyiksaan Khashoggi Disebut Terekam di Apple Watch, https://www.cnnindonesia.com/internasional/20181013152943-120-338235/momenpenyiksaan-khashoggi-disebut-terekam-di-apple-watch?, 13/10/2018

7United Nations General Assembly, A/RES/72/175, http://www.un.org/en/ga/search/view_doc.asp?symbol=A/RES/72/17529, January 2018
} 


\section{Method}

This article applies normative legal research that focuses on relevant international legal instruments dealing with the case discussed. It based on the statutory approach, case approach, and analytical/conceptual approach. The statutory approach is used to analyze some legal instruments e.g international conventions, declarations, and resolution or documents adopted by international organizations or institutions. Next, case approach is used to investigate the case discussed as well as its settlement mechanism while the analytical/conceptual approach mainly dealing with some analysis on legal concepts e.g jurisdiction and the violation of human rights.

\section{Result and Analysis}

\subsection{The International Human Rights Law's Protection to the Journalist's Activities}

A journalist is a person who writes for newspapers, magazines, or news websites or prepares news to be broadcast. ${ }^{8}$ Most journalists interested in writing about government programs and criticizing them. Their role is needed to articulate the need and feeling of the people, especially those whose their aspirations are not properly heard.

There are so many cases of violence to the press like Khasshogi here today, we can bravely say the right of the press is not assured. In fact, people need someone who dares to criticize the government as Khasshogi did, so they can represent their fellow citizen to express what they actually feel to their authorities. Many are oppressed by their government and cannot say a word, thus, we need press power to help to articulate the voice of the people. For example, Rebecca Henschke case when she tried to review about malnutrition and measles in Papua New Guinea. ${ }^{9}$ Even she has the license to cover her job, that license is useless in the New Guinea. She was interrogated for five hours straight by the police and army, then another 24 hours at the immigration office before getting deported to Jakarta. ${ }^{10}$

There is a risk for Journalists while they do their work because sometimes the criticized authority get upset and threat the Journalists indirectly. That was the main reason why journalists freedom of opinion and expression need to be protected internationally, Despite most countries' national laws, have recognized the freedom of the press as an exclusive provision, ${ }^{11}$ The freedom of expression itself is written in Article 19 Universal Declaration of Human Rights (UDHR) that states, "Everyone has the right to freedom of

\footnotetext{
8 Oxford Dictionaries, Journalist (2018).

https://en.oxforddictionaries.com/definition/journalist, (diakses pada Desember 2018)

9 Tirto News (2018), Kasus Rebecca BBC dan Gelapnya Kebebasan Pers di Papua, https:// tirto.id/ kasus-rebecca-bbc-dan-gelapnya-kebebasan-pers-di-papua-cEho, 4 Februari 2018

${ }^{10} \mathrm{Ibid}$

${ }^{11}$ See for example freedom of the press in section 2(b) of the Canadian Charter of Rights and Freedoms in Oliphant, B. (2013). Freedom of the Press as a Discrete Constitutional Guarantee. McGill Law Journal/Revue de Droit de McGill, 59(2), p.285.

https://doi.org/10.7202/1022310ar
} 
opinion and expression; this right includes freedom to hold opinions without interference and to seek, receive and impart information and ideas through any media and regardless of frontiers." It can be concluded from that article that freedom of expression is fundamental for every human being.

On Khashoggi case, his Freedom of Expression is not assured at all, because the main presumption of his assassination is his potency to lead the opposition group and his critics for the Saudi Government. If that presumption is correct, that means Saudi Government has violated Khashoggi rights to express his Opinion according to Article 19 UDHR.

Besides this declaration, there is Article 19 (2) International Covenant on Civil and Political Rights (ICCPR) which aim to ensure everyone right of expression undisputedly, stated as: "Everyone shall have the right to freedom of expression; this right shall include freedom to seek, receive and impart information and ideas of all kinds, regardless of frontiers, either orally, in writing or in print, in the form of art, or through any other media of his choice. ${ }^{12 "}$

Term 'everyone' in this article is meant to protect everyone without exception to express their thought and opinion freely. Expert views that this Article 19 has to be understood in related to Article $20 \mathrm{ICCPR}$, in which, the latest article is generally regarded as providing for further restriction of the right to freedom of expression. ${ }^{13}$ In addition, Article 19 should be read as an integral part of ICCPR, as stated by Tarlach McGonagle, as follows; "Read in the context of the ICCPR as a whole, Article 19 intersects with a number of other articles, such as those guaranteeing the right to life and freedom from torture, cruel, inhuman or degrading treatment, so as to provide a strong legal basis for the protection of journalists and the fight against impunity for the perpetrators of crimes against journalists." 14

General Comments No.34 on Article 19 of ICCPR concerning Freedoms of Opinion and Expression explicitly states that "Freedom of Expression is a necessary condition to the realization of the principles of transparency and accountability that are, in turn, essential for the promotion and protection of human rights."15 It means journalists rights to have freedom of expression is necessary considering their risk during performing their job. This General Comments may also have relevance to the case discussed. It says as follows:"...Journalists are frequently subjected to such threats, intimidation and attacks because of their activities. ... All such attacks should be vigorously investigated in a timely fashion, and the perpetrators prosecuted, and the victims, or, in the case of killings, their representatives, be in receipt of appropriate forms of redress." 16

\footnotetext{
${ }^{12}$ Article 19, International Covenant on Civil and Politic Rights

13 McGonagle, T. (2013). How to Address Current Threats to Journalism?: The Role of the Council of Europe in Protecting Journalists and Other Media Actors. Expert Paper, Doc, 1900(2013), 009, p. 8.

${ }^{14}$ Ibid, p.10.

${ }^{15}$ General Comments No.34 on Article 19 of ICCPR concerning Freedoms of Opinion and Expression, para 3.

16 Ibid, para 23.
} 
One should be noted that Saudi Arabia is not a State Party to the ICCPR. This means that there is no international legal obligation may be imposed on Saudi Arabia by referring to ICCPR. In a different situation, Turkey has signed ICCPR on 15 August 2000 and has also officially ratified it on 23 September 2003, by making Declarations and reservation. Turkey declares that it will implement ICCPR in accordance with the obligations under the Charter of the United Nations and will implement it only to the States with which it has diplomatic relations. In addition, Turkey declares that this ICCPR is ratified exclusively with regard to the national territory where Turkey's Constitution and the legal and administrative order are applied. ${ }^{17}$

The United Nations has a concern about Journalists Protections. This global organization adopted the UN Plan of Action on the Safety of Journalists and the Issue of Impunity as the outcome of a process initiated by the Intergovernmental Council of the International Programme for the Development of Communication (IPDC) in 2010. 18 Recently, the United Nations General Assembly (UNGA) at 29th January 2018 adopted Resolution No. A/RES/72/175 about the safety of journalists and the issue of impunity. ${ }^{19}$ Related to Khashoggi Case, the suspect has violated Article 1 and 10 from this resolution. Article 1 states:

"Condemns unequivocally all attacks and violence against journalists and media workers, such as torture, extrajudicial killings, enforced disappearances, arbitrary arrest and arbitrary detention, as well as intimidation, threats and harassment, including through attacks on, or the forced closure of, their offices and media outlets, in both conflict and non-conflict situations. ${ }^{20}$

The above provision condemns all violence against journalists in every way. The worst part about Khashoggi Case is that he was murdered while he did not exercise a journalism activity. At that time, Khashoggi was only looking for some files that prove he is not a married person because he wants to marry his fiancee.

Further, Article 10 of this resolution may be read as follows;

"Urges Member States to do their utmost to prevent violence, threats and attacks against journalists and media workers, to ensure accountability through the conduct of impartial, speedy, thorough, independent and effective investigations into all alleged violence, threats and attacks against journalists and media workers falling within their jurisdiction, to bring perpetrators, including those who command, conspire to commit, aid and abet or cover up such crimes to justice, and to ensure that victims and their families have access to appropriate remedies. ${ }^{21 "}$

17 United Nations Treaty Collection, Chapter IV Human Rights, 4 International Covenant on Civil and Political Rights,

https://treaties.un.org/Pages/ViewDetails.aspx?chapter=4\&clang=_en\&mtdsg_no=IV4\&src=IND\#EndDec

18 Ibid, p.13.

19 United Nations General Assembly, No. A/RES/72/175 about the Safety of Journalists and the Issue of Impunity, http://www.un.org/en/ga/search/view_doc.asp?symbol=A/RES/72/175

20 Ibid, Article 1

${ }^{21} \mathrm{Ibid}$, Article 10 http://www.un.org/en/ga/search/view_doc.asp?symbol=A/RES/72/175 
Based on the above provision, the stressing is about all member states to do their utmost prevent violence, to ensure accountability through the conduct of impartial, speedy, thorough, independent, all alleged violence, threats and attacks against journalists and media workers falling, and within their jurisdiction, to bring perpetrators, including those who command.

From what happened today, somehow Saudi authorities were not so cooperative in investigations, knowing the perpetrators are from Saudi Arabia. ${ }^{22}$ Turkish Minister of Foreign, Mevlut Cavusoglu said,"Until now, we have accepted Saudi Arabia's offers for cooperation with us without hesitation. However, looking at the cooperation now, since we can't find answers to the questions I just listed, this cooperation is not at the level we want." 23 His statement reflects a disappointment because Saudi Authorities is acted like unwilling to settle this case. Thus, Turkish Governments urged to initiate an international investigation for this case if their cooperation with Saudi Arabia reaches an impasse.

\subsection{Authorities that Have Obligations to Impose Legal Sanctions to the Alleged Perpetrators}

International human rights leaders expressed their deep regret and urge a serious investigation and trial. The Head of United Nations High Commissioner for Human Rights and OHCHR Michelle Bachelet emphasized that there must be conducted an entire examination for the violation of human rights committed against Mr. Khashoggi. She also appreciated the measure adopted by the governments of Turkey and Saudi Arabia in investigating and prosecuting the alleged doers but paid attention to the issue of accountability and justice that must be guaranteed by the bar. In addition, Bachelet suggested the inclusion of international experts in order to minimize the political character of the case in concern. ${ }^{24}$

The Special Rapporteur on the Promotion and Protection of the Right to Freedom of Opinion and Expression David Kaye pushed relevant authorities to immediately respond any case of journalist attack through UN bodies e.g Security Council, Human Rights Council, or by persuading the UN Secretary-General to launch an independent body investigation. This model of investigation, according to him, would provide credible findings to the international audiences. David Kaye expressed his anxiety that if this investigation does not execute, the facts will always be questioned. ${ }^{25}$

Every person in the world as a legal subject expects to get treated equally. Therefore we need the right and accurate law enforcement in order to avoid unfairness. Every victim must be looking for justice and the appropriate punishment for their

${ }^{22}$ CNN News (2018). Jaksa Ungkap Misi Pembunuhan Khashoggi Versi Arab Saudi, https://www.cnnindonesia.com/internasional/20181116173644-120-347191/jaksa-ungkapmisi-pembunuhan-khashoggi-versi-arab-saudi, 16/11/2018

${ }^{23}$ Reuters News (2018). Turkey may seek U.N. inquiry if Saudi cooperation reaches impasse, https://af.reuters.com/article/worldNews/idAFKCN1NQ033, November 21, 2018

${ }^{24}$ UN News, UN Rights Chief Says ‘Bar Must be Set Very High' for Investigation of Murdered Saudi Journalist,_https://news.un.org/en/story/2018/10/1024472

${ }^{25}$ UN News (2018). UN Expert Calls for International Investigation into 'Evident Murder' of Jamal Khashoggi, https://news.un.org/en/story/2018/10/102389223, October 2018 
perpetrator. In international law cases, sometimes litigation process have to go through the choice of forum because it is concerning between 2 (two) or more state parties and we have to decide which party have the rights to solve the cases.

Related to Khashoggi case, there are two relevant authorities to impose the legal sanction for the killer. There are 7 (seven) major principles to determine which parties have the proper rights to settle this case, ${ }^{26}$

1. Territoriality principle. Domain host state has the right to execute perpetrators by its penal law that happened in their territory. There are a few variations of this principle, inter alia:

a. subjective territoriality covers acts where the act or omission of the perpetrator (the conduct element) takes place in the territory;

b. objective territoriality covers instances where an individual acts outside the territory but the consequence element of the offense occurs within the territory; and

c. the 'effects doctrine', which is basically a loose version of objective territoriality, requiring that detrimental effects of the act be felt in the territory.

2. Flag principle. The flag could be an identity of a state, thus falling to their jurisdictions. Every place, vehicle, office, could be the state jurisdiction using flag principle. This principle underlines that a State has criminal jurisdiction over any act perpetrated on board of ships, aircraft, and spacecraft that uses its flag (nationally registered before such State)

3. Active personality (or nationality) principle. This principle suggests that a State may apply its criminal law to their nationals (citizen) who commit a crime in another country.

4. Protective (or security) principle. If there is a threat to its national security, this principle allows a state to apply their law for the sake of their nations.

5. Passive personality principle, implying that international law does allow a State to sue criminal acts committed against its nationals.

6. Universality principle. This principle allows a state to extend its laws to cover acts that are deemed to offend against the entire international community, such as genocide, crimes against humanity, war crimes, torture, piracy, slave trade and perhaps some forms of terrorism.

7. Representational principle (principle of vicarious administration of justice). Based on this principle, a state may apply its laws to crimes to which it has no connection, other than the fact that it has the suspect in custody and for some reason he or she cannot or will not be handed over to the state that does have jurisdiction under principles 1-5 above.

Based on the principles of jurisdiction, the qualified authority to impose the legal sanction for this case is Saudi Arabia, since Saudi Arabian authorities have filled the principles $1-5.27$ But in this case, the court proceeding will be held in Turkey. Basically, Turkish authorities have no proper right at all if we based on provision above, but based on principle 7 (Representational Principle) Turkey might hold the

\footnotetext{
${ }^{26}$ Liivoja, R. (2010). Service Jurisdiction under International Law. Melb. J. Int'l L., 11, 309. Some explanations are modified by Authors

27 Ibid
} 
tribunal to prosecute the perpetrators. ${ }^{28}$ Besides, there is another principle that push Turkey to held the tribunal, possibly it was the principle of Aut Dedere Aut Punere plays a role to give them the rights. It is recognized since the time of Hugo Grotius who says this principle as follows: "When appealed to, a State should either punish the guilty person as he deserves, or it should entrust him to the discretion of the party making the appeal." This principle play a big role to support international cooperation and have fight impunity since it recognized. In this modern world, many experts concerned about the possibility to punish an innocent person. Therefore terms "punishment" replaced with "prosecution." 29

Since the court will be held by the Turkish authorities, it is reasonable to assume the impartial judgments would be granted During the investigations, Saudi authorities were assessed not so cooperative enough to settle this case, because of that some parties afraid if the court held by Saudi Arabia, the judgment would not impartial. The remaining problem is Saudi Authority denied extradition request. Saudi Arabia Minister of Foreign Affairs Adel Al-Jubeir, during the press conference at Riyadh, stated; "We do not extradite of surrender our citizens (to another country)." 30

\section{Conclusion}

The Enforcement of Protections of journalists is far from what was expected, although there are so many human rights instruments that cover the issue of freedom of expression. While performing their job, journalists can risk their own life. In facts, not all of those who are in power respect the news written by journalists that may defame their reputation. Khashoggi case can be the perfect example of how the right of expression was not fully respected and protected. Whatever international protection to the journalists have been stipulated in Article 19 UDHR, Article 19 ICCPR, Article 1 and 10 UNGA, in fact, there is no guaranteed for its implementation. Therefore, the protection to the freedom of expression for journalists, and also every person in the world, is needed.

One hand, Saudi Arabia may argue that its national court has jurisdiction to try the present case based on the Territorial Principle. In facts, the initial investigation indicates that Saudi authorities seem do not so cooperative that increasing the suspiciousness about the impartiality. On the other hand, there is a legal principle that supports Turkish authorities to start the court proceeding. It is generally known as the principle of Aut Dedere Aut Punere, emphasizing that every country is obliged to sue and punish every crime that occurs within the territory of their country. Since this assassination was committed in Istanbul, Turkey would be the most competence

${ }^{28}$ This may apply the concept "international criminal law in the meaning of internationally authorized municipal criminal law" and "international criminal law in the meaning municipal criminal law common to civilized nations." See Diantha, I. M. P. (2014). Hukum Pidana Internasional Dalam Dinamika Pengadilan Pidana Internasional. Jakarta: Prenada Media Group, p. 5-6

${ }^{29}$ Grotius, H. (1925). De Jure Belli ac Pacis, Book II, chapter XXI, section IV (English translation by Francis W. Kelsey (Oxford/London: Clarendon Press/Humphrey Milford, 1925), pp. $527-529$ at 527).

30 CNN News (2018). Saudi Tolak Permintaan Ekstradisi Pembunuh Khashoggi ke Turki, $10 / 12 / 2018$ 
country to bring the perpetrator into a justice system. Whatever current Turkey's image on freedom of expression and media freedom, ${ }^{31}$ in facts, international society, as represented by some international organizations, seems support Turkey position to launch an investigation over the present case.

The remaining legal issue is about the willingness of Turkey's tribunal to apply international human rights concept and norms in its legal proceeding over this case. What this article would like to address is that this case very much dealing with the human rights issue, particularly freedom of expression and press (media), that intentionally puts international human rights law in a lex specialist position over general concept of public international law, international relations, diplomatic law, transnational crime, and other aspects that related to the present case. Therefore, once the finding or judgment was given by Turkey's court, it will be a further interesting legal research to assess whether or not the international human rights standard are properly considered and applied.

\section{List of Reference}

\section{Book}

Diantha, I. M. P. (2014). Hukum Pidana Internasional Dalam Dinamika Pengadilan Pidana Internasional. Jakarta: Prenada Media Group.

Grotius, H. (2012). English Translations of Hugo Grotius' De Jure Belli Ac Pacis And Related Works. Oxford/London: Clarendon Press/Humphrey Milford, 1925

\section{Journal}

Fernandez, J. M. (2018). Special Report: The Qatar-Gulf Crisis: The Attack on Media Freedom and The West's Loss of Moral Authority. Pacific Journalism Review: Te Koakoa, 24(2), 158-164. https:/ / doi.org/10.24135/pjr.v24i1.401

Liivoja, R. (2010). Service Jurisdiction under International Law. Melb. J. Int'l L., 11, 309.

McGonagle, T. (2013). How to Address Current Threats to Journalism?: The Role of the Council of Europe in Protecting Journalists and Other Media Actors. Expert Paper, Doc, 1900(2013), 009

Oliphant, B. (2013). Freedom of the Press as a Discrete Constitutional Guarantee. McGill Law Journal/Revue de Droit de McGill,59(2), 283-336., https://doi.org/10.7202/1022310ar

\section{Online/World Wide Web}

CNN News, Jaksa Ungkap Misi Pembunuhan Khashoggi Versi Arab Saudi, Retrieved from https://www.cnnindonesia.com/internasional/20181116173644-120347191/jaksa-ungkap-misi-pembunuhan-khashoggi-versi-arab-saudi, CNN News, Klaim Saudi dan Upaya Jauhkan Pangeran dari Kasus Khashoggi,

31 Freedom of expression and media freedom have been a major priority in the work of the Commissioner for Human Rights regarding Turkey, Memorandum on Freedom of Expression and Media Freedom in Turkey, Commissioner for Human Rights, Council of Europe, CommDH(2017)5, Strasbourg, 15 February 2017, para 7. 
Retrieved

from

https://www.cnnindonesia.com/internasional/20181020220049-120-

340106/klaim-saudi-dan-upaya-jauhkan-pangeran-dari-kasus-khashoggi Sabtu, 20/10/2018

CNN News, Kronologi Kisruh Jamal Khashoggi, Wartawan Pengkritik Saudi, Retrieved from

https://www.cnnindonesia.com/internasional/20181019100032-120339720/kronologi-kisruh-jamal-khashoggi-wartawan-pengkritik-saudi, 20/10/2018

CNN News, Saudi Tolak Permintaan Ekstradisi Pembunuh Khashoggi ke Turki, Retrieved from https://www.cnnindonesia.com/internasional/20181210102433-120352380/saudi-tolak-permintaan-ekstradisi-pembunuh-khashoggi-ke-turki, $10 / 12 / 2018$

Reuters News, Turkey may seek U.N. inquiry if Saudi cooperation reaches impasse, Retrieved from, https://af.reuters.com/article/worldNews/idAFKCN1NQ033, , November 21, 2018

Tirto News, Kasus Rebecca BBC dan Gelapnya Kebebasan Pers di Papua, Retrieved from https://tirto.id/kasus-rebecca-bbc-dan-gelapnya-kebebasan-pers-dipapua-cEho, 4 Februari 2018

UN News, UN Expert Calls for International Investigation into 'Evident Murder' of Jamal Khashoggi, Retrieved from https://news.un.org/en/story/2018/10/1023892, 23 October 2018

UN News, UN Rights Chief Says 'Bar Must be Set Very High' for Investigation of Murdered Saudi Journalist ${ }_{2}$ Retrieved from https://news.un.org/en/story/2018/10/1024472, 30 October 2018

United Nations Treaty Collection, Chapter IV Human Rights, 4 International Covenant on Civil and Political Rights, https://treaties.un.org/Pages/ViewDetails.aspx?chapter=4\&clang=_en\&mtdsg no $=$ IV-4\&src $=$ IND\#EndDec

\section{Legal Document}

General Comment No. 34 Article 19 ICCPR: Freedoms of Opinion and Expression

International Convention for the Protection of All Persons from Enforced Disappearance (CCPR/C/GC/34)

International Covenant on Civil and Political Rights

Memorandum on Freedom of Expression and Media Freedom in Turkey, Commissioner for Human Rights, Council of Europe, CommDH(2017)5, Strasbourg, 15 February 2017

United Nations General Assembly Resolution No. A/RES/72/175 concerning the Safety of Journalists and the Issue of Impunity

Universal Declaration of Human Rights 